\title{
The Business Case for Sustainability
}

In this chapter, I will discuss how companies actually address sustainability challenges. First, the chapter will begin with examples of different corporate approaches to taking responsibility for sustainability. Second, I will explore how companies are viewed from the stakeholder point of view, so how others outside the company view the managers' motivation for engaging in corporate responsibility. Although the majority of companies are still motivated by risk reduction and/or branding in their sustainability work, this chapter will reframe the motivation into something more positive - a business opportunity.

The chapter will analyze four key happenings which triggered focus on sustainability and changed the environment: the Nike sweatshop case; the Arthur Andersen corruption case; the VW case on incorrect emission reporting and, finally, the Rana Plaza building collapse case. The model of sustainability and change, from ignoring that there is a corporate challenge, to reacting, defending, accommodating, and finally moving to a proactive approach to sustainability will be used as a framework for business development and evaluation through the four cases. In essence, the journey will be on the transition from reducing unsustainability to a focus on creating sustainability (Hoffmann, 2018). 


\subsection{Who Initiates Sustainability Focus in Companies: And What Is the Outcome?}

There are a multitude of drivers motivating leaders and companies to pursue sustainability and address the company's responsibilities. The position and role of the person within the corporate hierarchy initiating such engagements is an important antecedent of how the company will proceed on sustainability and where it will end up - that is, what will be the result. The importance to individual preferences in the sustainability process is often overlooked and I will therefore include it in this chapter.

In a study following four companies after the concept of corporate responsibility and addressing sustainability issues was introduced, the impact of individuals in the sustainability process comes forward. The person in charge of introducing the concept, the "translators", had chosen very different approaches to apply and follow up the corporate responsibility process. One way to explain the difference in strategies and outcomes is that each of the four employees had different power and impact within their respective organizations. Another is that the employees had different ways of working — different personalities (Ditlev-Simonsen, 2010).

Starting with the impact of position, assume the person introducing the corporate responsibility and sustainability focus into the company is part of the top management team. This person does not necessarily have to consult with other employees. This manager can make his/her own interpretation of the company's responsibilities with regards to sustainability and implement it as he/she deems appropriate. If the "translator" is the Director of Public Relations/Communication, the initiatives are likely to be closely related to communicating the company's sustainability focus, even though this might not necessarily be part of the company culture. There are many examples of company responsibility and sustainability reports containing great presentations of the company's sustainability engagement, but if you asked a random employee, they would not know anything about it. It is also common to find companies, which issue non-/extra-financial reports full of great sustainability stories and printed on recycled paper. However, these same companies' corporate annual reports do not mention social responsibility or sustainability at all. This signals that the issues are most likely not integrated in the company's day-to-day operations. 
So, we see that the role, position, and even personality of the person who starts the sustainability focus process impacts the degree of a company's engagement and focus on this field. If the Head of Investor Relations as opposed to the Director of Communications initiates a company's sustainability engagement, there tends to be a much larger investor focus.

We also see that if the person in charge of the company's sustainability engagement is at the bottom of the company's hierarchy, driven by for example personal interest and/or delegated the responsibility to a senior manager, initiatives rarely succeed without greater awareness, support, and buy-in from colleagues. So, if an employee at the lower echelons of the organization manages to make sustainable changes in the company, it is likely to have a more encompassing effect. Still, as will be discussed in Chap. 7, that sustainability is anchored in top management is a prerequisite for a successful sustainability process.

\subsection{Perception of Management Motivation for Social Responsibility}

In addition to responsibility and sustainability drivers anchored in position and personality, managers/companies are motivated by different goals. Asking board members, employees at two NGOs, World Wide Fund for Nature (WWF) and Amnesty International, and master students what they assumed motivated senior managers in the 20 largest companies in Norway to pursue corporate responsibility, the answers were surprisingly aligned. One would have thought that critical NGOs were likely to be more skeptical about managers' motivations, than for example corporate board members (Ditlev-Simonsen \& Midttun, 2011).

The respondents, the board members, NGO employees, and students were asked to rate ten different motivation factors why managers pursue corporate responsibility. These include: Profit (short-term revenue) (Friedman, 1970), Value maxim (long-term profit) (Jensen, 2001), Stakeholdership (pressure from out or inside) (Freeman, 1984), Cluster building (that companies in the same sector "push" each other) (Porter, 1998), Branding (to improve reputation) (Fombrun, 2005), Innovation (competitive advantage through better products) (Kanter, 1999), 
Copying and imitating (pursuing sustainability because everybody else does so) (DiMaggio \& Powell, 1983), Ethics and morals (more deeply motivated to do and behave "good") (Hursthouse, 1999), Managerial discretion (the discrete individual motivation) (Bhattacharya et al., 2008; Williamson, 1964) and, finally, Sustainability (World Commission on Environment and Development, 1987) (motivated by not compromising the future for the next generations).

The results show that the three groups of respondents assume the key motivator for sustainability among senior managers was Branding, so to look good. The respondents in general did not think ethics and morals were key drivers for responsibility or sustainability—except among students. Business graduate students thought managers' motivation was more driven by sustainability than the board members and NGOs. Asking the same three groups, what they thought should be the key drivers for sustainability the three groups yet again agreed; Sustainability and Ethics and morals should be the key drivers for behaving socially responsible.

This shows that together students, leaders, and NGOs in general are rather skeptical to senior leadership. It can seem like making money in itself is against morality and sustainability. But as addressed in earlier chapters, this is not necessarily true. The goal should be to satisfy economic, environment, and social issues at the same time- the Triple Bottom Line.

Many companies still use sustainability engagement as a marketing tool to develop their brand. Companies want to differentiate their products as those that are better to the environment and really care about the society around. Some companies use the sustainability "element" in their marketing program, without the concept being part of the company as such, but as more of a superficial effect. If something happens revealing that the sustainability engagement is barely a thin layer of fluffy words outside the company, the loss of brand value can be significant. A good example that will be addressed later is VW's deceiving emission testers in 2015 , which led to a drop in brand value from US $\$ 31$ billion to US $\$ 21$ billion (Brand Finance, 2015).

For many leaders approaching sustainability is motivated by reducing risk, not to capture the opportunities. When reflecting over the last four decades' scandals and tragedies, they are almost all associated with responsibility and sustainability issues — environment damage, poor treatment of people, bad working conditions, child labor, and behaving irresponsibly through bribing 
and corruption. However, the positive effect, the opportunities of supporting the company brand and reputation, also has great potential.

\subsection{The Value of Corporate Responsibility in a Sustainable Setting}

Up to 1990s a large part of a company's value was in "tangible" assets. Tangible assets are something that can be touched, like machinery, cars, products, and so on. As business developed and new companies and products like Facebook, Amazon, Twitter, Google, and so on emerged, factories with traditional machinery are to a lesser degree necessary to make business. The companies mentioned are now among the worlds' largest companies and their value is based on "intangible" assets. Intangible assets are business concepts, goodwill, intellectual capital, patents, brands, reputation, and so on. Figure 5.1 illustrates the shift from tangible to intangible elements as part of the company's market value.

Today intangible assets contribute to more than 88 percent of the average business' value (Juetten, 2014). Reputation is a substantial part of this intangible value. For the S\&P 500, it is estimated that reputation is more than 20 percent of the gross market capitalization (Sustainable Brands, 2019), ten percent of that is linked to the company's Corporate Responsibility engagement.

In contrast to tangible assets, intangible assets can be damaged resulting in a significant drop in the value of the company, if the company is associated with negative events. Such events are usually associated with sustainability issues like revealing poor working conditions among suppliers in low cost countries, environmental damage, and corruption.

Some companies are good at presenting themselves as sustainable, establishing a brand reflecting sustainability. Still, and as I will show in the cases below, companies which have presented themselves as responsible are not necessarily so. Other companies behaving sustainably are not given credit for that as they have not been marketing their engagements in societal and environmental issues.

Before the "digital age" companies' operations, typically in poor countries, could entail unacceptable conditions like low wages, bad working conditions, tragedies, and environmental damage. Situations like this was 


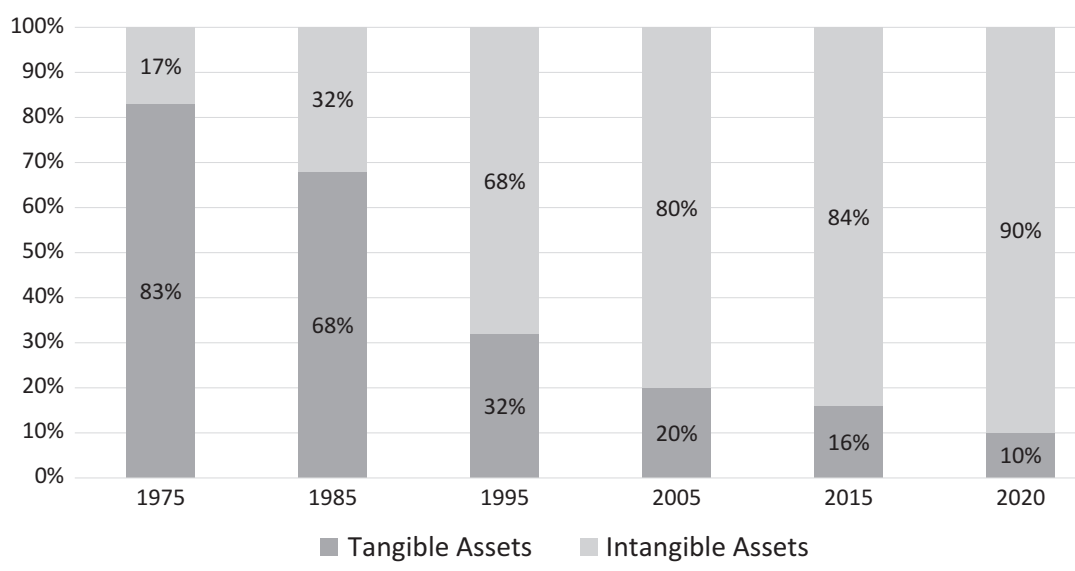

Fig. 5.1 Components of S\&P market value

hard to detect and less likely to be followed up. With today's digital tools, such conditions can instantly be made public through photos taken by phones and distributed all over the world through social media like Twitter, Instagram, and Facebook. The risk of such scandals happening to companies is a great motivation factor for ensuring good conditions in the supply chain. It takes many good initiatives and activities to build a good reputation, and only one bad one happening to lose it.

\subsection{Stages and Strategies Toward Responsible Sustainable Business}

Maybe the key motivator for companies today to pursue sustainability and responsible behavior is avoidance of tragedies, accidents, and scandals associated with irresponsible behavior. Naturally, most companies which face such situations have to act in one way or the other. But, maybe more important is the impact such tragedies and scandals have on the majority of other companies. Very many of these investigate their own operations when scandals and tragedies come forward and take actions so that they will not end up in similar situations. 
Already in 1974, Ian Wilson argued for taking a proactive strategy, not to try to stop societal pressure for change, but rather "moving quickly beyond mere compliance to develop imaginative solutions that have the effect of internalizing the new societal expectations in the day-today operations of the corporate system" (Wilson, 1975). He suggested the following four possible business strategies, arguing that the last one, Proaction, should be the key focus.

\section{Reaction \\ 2. Defense \\ 3. Accommodation \\ 4. Proaction}

These strategies are equally relevant today, almost half a decade later. Applying the four categories to evaluate the level of maturity of corporate approach to sustainability and corporate responsibility can be very useful. Several similar approaches to benchmark and evaluate corporate performance relative to different stages have been suggested. The following five stages of organizational learning are suggested by Simon Zadek.

1. Defensive (Deny practices, outcomes, or responsibilities),

2. Compliance (Adopt a policy-based compliance approach as a cost of doing business),

3. Managerial (Embed the societal issues in their core management process),

4. Strategic (Integrate the societal issues into their core business strategies), and

5. Civil (Promote broad industry participation in corporate responsibility) (Zadek, 2004).

Neither of these models include the "Ignore" phase where the company simply ignores the challenges at stage (Ditlev-Simonsen, 2014). On top of Zadek's model is "Civil" related to "long-term economic value by overcoming any first-mover disadvantages and to realize gains through collective action". This stage as formulated does not explicitly involve innovation, being ahead of the market and creating new products. Furthermore, none 


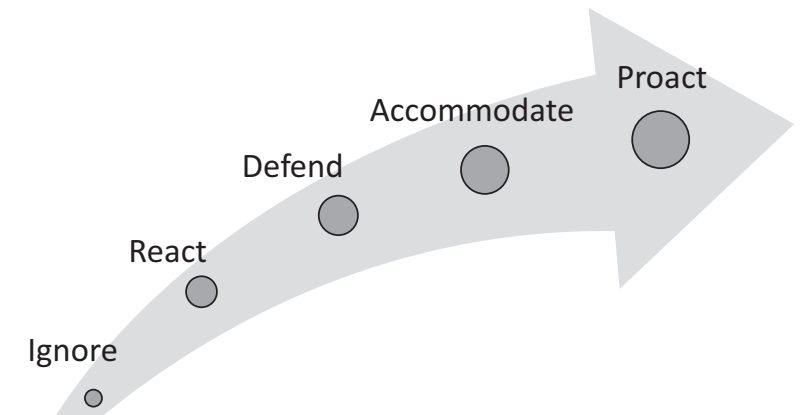

Fig. 5.2 The stage model—Stages in sustainability approaches and change

of the models are directly aimed at responsibility and sustainability. A revised model combining the Wilson and Zadek model to explicitly focus on sustainability is based on the following five steps and Fig. 5.2.

\section{Revised stage model for sustainability strategy and examples of claims}

1. Ignore-not being aware of or overlook the social and environmental issues faced.

2. React-recognizing the issues and reacting - "There is something called sustainability and responsibility 'out there'-but not relevant for us".

3. Defend-conveying that the issue is not part of the company responsibility. "This is not our problem. Environmentalists and human right organizations are wrong. It is other actors to clean up the problem."

4. Accommodate-agree to clean up what the company is criticized for. "Have a look at our newly released sustainability report, it is attached to our annual report. We are thinking responsibility and have installed all LED light bulbs and contract on acceptable working conditions with our suppliers", "We only purchase from environmentally certified companies", and "We are sorting our waste".

5. Proact-change attitude and foresee challenges and perceive these as innovative opportunities to position the company. "We are no longer focusing on reducing negative impact on society but see sustainability as a business opportunity". "We are applying a new sustainable business model providing system change", "We are designing for a circular economy", and "We word with different stakeholders to be part of a circular economy." 
Awareness of the different stages and through benchmarking itself, a company facilitates the process of improving sustainability operations. This is a good tool for that. I will illustrate and analyze the Stage model and strategies with four cases which are to a certain degree considered "game changers" with regards to environmental and social issues.

I begin with the Nike sweatshop case on poor working conditions in poor countries. The second case is about Arthur Andersen's, one of the world's largest accounting firms, involvement in corruption. The third case is the VW case on tampering emission technology and the fourth and final case is the Rana Plaza Bangladesh case where the factory where people were working under unacceptable conditions collapsed killing many employees.

First, I will present the cases; thereafter I will apply them according to the model and the five stages. It is important to note these five stages are not associated to any particular timeframe. Although companies a few decades ago were more likely to be at the first stage, ignoring any sustainability challenges, there are still many companies employing this strategy. Other companies have gone through all the five stages and are now continuing in the Proaction phase in one part of their operations, whereas the company is at level one, Ignore, in other parts of its operations.

\subsection{Four Cases: Nike, Arthur Anders, Volkswagen, and Rana Plaza}

This is a presentation of four cases and the process the companies went through after the misbehavior was detected, through the process of response and the final result.

\section{Nike-from underperformance to leading sustainability change}

In the 1960s, Nike's business model focused on selling innovative, quality, and affordable product running shoes. They outsourced all production to Asia, while their competitors were still using high wage European labor. In the 1980s, Nike discovered the importance of marketing. It started building 


\section{(continued)}

a brand to create a long-lasting emotional tie with the consumer, while the product became the most important marketing tool (Willigan, 1992). ${ }^{1}$

Then in the 1990s, Nike was barged into by media stories and vivid imagery from major news outlets and human rights groups of exploitation in their suppliers' factories in Indonesia, Vietnam, and Pakistan. ${ }^{2}$ Allegations of refusing to pay minimum wages, forcing overtime, using child labor, corporal punishment, and poor working conditions filled the headlines. ${ }^{3}$ For years, Nike strongly denied allegations. ${ }^{4}$ They maintained it was not the company's responsibility to investigate working conditions of its suppliers' factories. To quell its critics, Nike introduced a code of conduct for suppliers with expectations for suppliers to abide, but implementation and monitoring was flawed. ${ }^{5}$ It was also unconvincing for investors and the public. A Nike employee even leaked an internal audit by Ernst \& Young, documenting unsafe conditions for workers, undermining Nike's claims. ${ }^{6}$

Coincidently facing falling stock prices and weak sales, ${ }^{7}$ then Nike CEO Phil Knight in a 1998 speech conceded that "the Nike product has become synonymous with slave wages, forced overtime, and arbitrary abuse." 8 This marked the turn around. Nike undertook a number of initiatives to fully understand supplier labor practices. They set up an internal monitoring system, created a corporate responsibility and compliance division with field staff conducting local audits, and established rigorous requirements to be accepted as a supplier. It joined various initiatives organized by NGOs and invited its toughest critics to review Nike's corporate responsibility report. Nike eventually published 90 percent of its supplier list for greater transparency. Today, Nike boosts a history of taking a stand on social and environmental issues ${ }^{9}$ to the extent of being accused of commercializing social justice. ${ }^{10} 11$

\footnotetext{
${ }^{1}$ https://hbr.org/1992/07/high-performance-marketing-an-interview-with-nikes-phil-knight.

${ }^{2}$ https://depts.washington.edu/ccce/polcommcampaigns/NikeChronology.htm.

${ }^{3}$ https://apnews.com/article/d3c0fa434245b6b92f83f05278f3cd2d.

${ }^{4}$ https://www.nytimes.com/1997/11/08/business/nike-shoe-plant-in-vietnam-is-called-unsafe-forworkers.html.

${ }^{5}$ Doorey, D. J. The Transparent Supply Chain: from Resistance to Implementation at Nike and Levi-Strauss. J Bus Ethics 103, 587-603 (2011). https://doi-org.ezproxy.library.bi.no/10.1007/ s10551-011-0882-1.

${ }^{6}$ https://www.nytimes.com/1997/11/08/business/nike-shoe-plant-in-vietnam-is-called-unsafe-forworkers.html

${ }^{7}$ https://business.nmsu.edu/ $\sim$ dboje/nikestockstories.html.

${ }^{8}$ Cushman, J.: 1998, "Nike Pledges to End Child Labor and Increase Safety", New York Times (13 May 1998).

${ }^{9}$ https://purpose.nike.com/how-we-stand-up-for-equality.

${ }^{10}$ https://www.prweek.com/article/1492939/why-brands-will-follow-nike-social-justice.

${ }^{11}$ Hayhurst, L. M. C., \& Szto, C. (2016). Corporatizating Activism Through Sport-Focused Social Justice? Investigating Nike's Corporate Responsibility Initiatives in Sport for Development and Peace.JournalofSportandSocialIssues, 40(6),522-544.https://doi.org/10.1177/0193723516655579.
} 


\section{Arthur Andersen-from perceived as a responsible company to bankruptcy}

At the start of 2001, Arthur Andersen \& Co (AA) was one of the world's largest and influential accountancy firms with 85,000 employees generating $\$ 9$ billion in revenue from over 30,000 clients. ${ }^{12}$ The next year, AA declared bankruptcy and became the first accounting firm to have ever been convicted of a felony. The story of their downfall starts with the spectacular demise of one client, Enron, once ranked 7th on Fortune's 500 list of world's largest firms. AA provided Enron external auditing services, verifying the integrity of their financial statements to protect shareholders and potential investors.

In August 2001, Sherron Watkins, an Enron VP wrote an anonymous letter to the new CEO regarding concerns about the firm's accounting and also discussed it with a former colleague and audit partner at AA's Houston office, James Hecker. Although Enron was not his account, he took it to the partners. Enron was an important client, generating 27 percent of Houston office's revenue, 25 million in audit fees, and 27 million in consulting fees. On October 12th an AA lawyer contacted a senior partner at the firm to remind him that Andersen does not retain documents that are no longer needed resulting in a massive amount of Enron documents being shredded. ${ }^{13}$ Shortly after, Enron announced a massive quarterly loss, the SEC initiated an investigation. By December, Enron filed for bankruptcy after it came to light, the company hyperinflated its revenues by 100 billion and hid debt using deceptive and fraudulent accounting tactics.

All attention turned to AA, their auditor. ${ }^{14}$ The CEO denied having any previous knowledge of any of Enron's illegal behavior, rather argued the business model failed and information was withheld during audits. ${ }^{15}$ First, the firm denied wrongdoing, arguing that the email to the Houston partners to shred the documents was just a reminder, urging compliance with a legal document-retention policy. ${ }^{16}$ Then, AA denied knowledge at the executive level and pushed blame on a rogue partner. ${ }^{17}$ Shortly after the indictment, the CEO resigned. AA was convicted of obstruction of justice and

(continued)

\footnotetext{
${ }^{12}$ https://www.forbes.com/2002/03/07/0307andersen.html?sh=508b50575001.

${ }^{13}$ The Fall of Enron, Paul M. Healy and Krishna G. Palepu, Journal of Economic PerspectivesVolume 17, Number 2-Spring 2003-Pages 3-26.

${ }^{14}$ Red Flags in Enron's Reporting of Revenues and Key Financial Measures. Bala G. Dharan \& William R. Bufkinds, Governance and Intermediation Problems in Capital Markets: Evidence from the Fall of Enron (forthcoming 2004, Harvard Business School working paper 03-027.

${ }^{15}$ https://www.theguardian.com/business/2002/jan/21/corporatefraud.enron.

${ }^{16}$ https://www.economist.com/finance-and-economics/2005/06/02/not-guilty-after-all.

${ }^{17}$ https://www.wsj.com/articles/SB1011096414335724680.
} 


\section{(continued)}

witness tampering for purging the Enron documents and surrendered its rights to practice before the SEC by August 2002. Even though the Supreme Court unanimously overturned the felony conviction 3 years later, AA's reputation was destroyed overnight, many of its clients ended their relationship with AA and the company was dissolved after 89 years of business.

\section{VW Emissions Scandal-from being a top-rated responsible company to an under-performer}

In March 2014, three researchers from the University of West Virginia presented a paper that would inadvertently ignite one of the largest scandals in automotive history. Since 1966, when the United States began setting emissions standards, new vehicles were always tested under controlled laboratory conditions on a stationary test rig in order to gauge $\mathrm{CO}_{2}$. These researchers asked the question whether clean diesel engine cars have the same emissions under real-world driving conditions as in the lab. ${ }^{18}$ After test driving three different Volkswagen (VW) cars and a BMW, they found that no, the emissions were significantly larger. Sitting in the audience was the deputy head of CARB (California Air Resource Board), who subsequently put together a team of experts to investigate the discrepancies and engaged the Environmental Protection Agency (EPA)

CARB and EPA sought clarification from VW regarding the discrepancies, ${ }^{19}$ specifically that VW cars had nitrogen oxide emissions up to 40 times higher than permitted levels. ${ }^{20} \mathrm{VW}$ attributed them to technical issues and issued a limited recall to fix the problem. ${ }^{21}$ In September 2015, the US EPA found that VW cars had a defeat device, illegal manipulation software that recognized when emissions were being tested, resulting in tests meeting standards. Only after the EPA threatened to withhold approval for its 2016 VW and Audi diesel cars to be sold on the US market, VW formally acknowledged that it rigged its cars and manipulated emissions tests. ${ }^{22}$

(continued)

\footnotetext{
${ }^{18} \mathrm{https}$ ://www.spiegel.de/international/business/the-three-students-who-discovered-dieselgatea-1173686.html.

${ }^{19}$ https://www.nytimes.com/2015/10/24/business/international/directors-say-volkswagendelayed-informing-them-of-trickery.html.

${ }^{20}$ https://www.bbc.com/news/business-34324772.

${ }^{21}$ https://www.npr.org/sections/thetwo-way/2015/09/23/442818919/volkswagen-ceoresigns-saying-he-s-shocked-at-emissions-scandal.

${ }^{22}$ https://www.reuters.com/article/us-usa-volkswagen-deception-insight-idUSKCN0RO 2IP20150924.
} 
(continued)

The US CEO publicly admitted VW "totally screwed up". ${ }^{23}$ However, senior management denied having any previous knowledge of the deception and blamed it on a few software engineers. The CEO immediately took responsibility and formally resigned. There are conflicting reports, when exactly management was aware going back as far as 2005, while regulators estimated executives must have known for at least over a year. In 2017, VW pleaded guilty to three criminal charges ${ }^{24}$ and subsequently spent an estimated 34.69 billion USD in fines and settlements. ${ }^{25}$

The VW scandal snowballed to include Volvo, Daimler, ${ }^{26}$ Renault, Jeep, Fiat, and many other major car manufacturers, which were also using defeat devices and manipulating emissions data. ${ }^{27}$ However, VW was the first and it is just a matter of luck that the researchers from University West Virginia (UWV) had a limited budget to rent VWs and could not afford to use Mercedes in their study. In response to the political fallout, VW revised their company strategy and culture to transform itself to be a pioneer in sustainable mobility with the goal of becoming carbon neutral by $2050 .{ }^{28}$

\section{Rana Plaza-the effect of public awareness of irresponsible companies}

In late April 2014 in Dhaka, Bangladesh, workers noticed large, growing cracks in the concrete pillars that support the eight-story garment factory complex, Rana Plaza. ${ }^{29}$ An engineer quickly assessed the building as unsafe, evacuating everyone. ${ }^{30}$ However, the managers downplayed the risks. They had a deadline to meet with the 30 global brands that deducted 5 percent every week from every late order. Threatening to withhold monthly pay, all the garment workers went back to work the next day. Shortly after 9:00, the building collapsed killing over 1100 and injuring another 2400 .

(continued)

\footnotetext{
${ }^{23}$ https://www.euronews.com/2015/09/22/volkswagen-admits-it-totally-screwed-up-asemissions-rigging-scandal-spreads.

${ }^{24}$ https://www.justice.gov/opa/pr/volkswagen-ag-agrees-plead-guilty-and-pay-43-billioncriminal-and-civil-penalties-six.

${ }^{25} \mathrm{https}$ ://www.reuters.com/article/us-volkswagen-results-diesel-idUSKBN2141JB.

${ }^{26} \mathrm{https}$ ///www.justice.gov/opa/pr/us-reaches-15-billion-settlement-daimler-ag-overemissions-cheating-mercedes-benz-diesel.

${ }^{27}$ https://www.motoringresearch.com/car-news/not-just-vw-30-dirty-diesels-accusedemissions-cheating/.

${ }^{28}$ https://www.dw.com/en/how-volkswagen-wants-to-drive-e-mobility-revolution/a-47586417.

${ }^{29} \mathrm{https} / / /$ www.theguardian.com/world/2014/apr/19/rana-plaza-bangladesh-one-year-on.

${ }^{30}$ https://web.archive.org/web/20180425114547/https://www.nytimes.com/2013/05/03/world/ asia/engineer-arrested-in-bangladeshi-building-collapse.html.
} 


\section{(continued)}

From 2004, the garment industry, which is very labor intensive, exploded in Bangladesh, thanks to having the lowest wages in the world. By 2013, it was the second largest exporter of clothes and provided the country with 80 percent of its export earnings. ${ }^{31}$ Hundreds of factories were built every year with little to no planning or oversight. ${ }^{32}$ The Rana Plaza building was not designed to house factories with heavy machinery or the additional three floors that were added. Although Western brands had set up systems to monitor pay and working conditions in their supply chain, they did not think of conducting building inspections.

In the aftermath, some companies such as Primark quickly acknowledged they sourced from Rana Plaza and pledged to compensate its victims. ${ }^{33} \mathrm{~A}$ joint fund was established with the goal of raising $\$ 30$ million for the victims and families, while contributions were voluntary. Brands such as Benneton, Walmart, C\&A, and Carrefour immediately denied having any connections. Many firms donated without confirming production, claimed they stopped ordering well before the disaster, or downplayed their relationship (C\&A, Mango, and Walmart). ${ }^{34}$ Only after Benetton labels were found in the rubble and documents showing work orders were publicized, five days after the disaster, the company acknowledged it had placed a one-time order. ${ }^{35}$ It donated $\$ 500,000$ USD to the respectable NGO, Bangladesh Rural Advancement Committee (BRAC) collecting money for the victims.

For two years, Benetton refused to take any responsibility. Only after a new CEO came onboard and activists launched a campaign on social media at select store locations, questioning their socially conscious branding with the slogan "Benetton: show your true colors", depicting a Bangladeshi woman rescued from the Rana Plaza rubble, the company decided to contribute an additional \$1.1 million USD to the BRAC victim's compensation fund. The calculation was based on doubling a PricewaterhouseCoopers (PwC) estimate that Benetton accounted for about 2 percent of Rana Plaza's output for the prior year, sourcing 266,000 shirts.

Most firms including Benetton rapidly signed up to the Accord on Fire and Building Safety in Bangladesh (ACCORD), a joint initiative to verify the

(continued)

\footnotetext{
${ }^{31}$ https://jp.reuters.com/article/instant-article/idUSL4N0PL2ED20140710.

${ }^{32}$ https://www.theguardian.com/world/2014/apr/19/rana-plaza-bangladesh-one-year-on.

${ }^{33}$ https://www.aljazeera.com/opinions/2015/4/24/when-workers-die-no-company-can-walk-away.

${ }^{34} \mathrm{https}$ //www.theguardian.com/world/ng-interactive/2014/mar/17/rana-plaza-factory-collapsecompensation-interactive-guide.

${ }^{35}$ https://www.nytimes.com/2013/05/01/world/asia/retailers-split-on-bangladesh-factory-collapse.html?_r=0.
} 
(continued)

structural integrity of Bangladeshi garment factories. ${ }^{36}$ Only one year later, ACCORD has shown progress with global brands beginning to pull out orders from around 30 percent of the garment factories housed in unsafe buildings impacting 1.5 million workers. ${ }^{37}$

\subsection{Response Analysis of the Four Cases}

The following is an analysis of the four cases relative to the six stages in the response framework (Fig. 5.2). This is the model and the analysis is a good tool for benchmarking one's own company performance as a basis for developing a sustainability strategy.

\section{Stage 1: Ignore}

This is a stage where companies ignore that they might have sustainability challenges, or they may be just completely unaware of them. Nike was a company aware of its own unsustainable behavior but chose to ignore the fact that its suppliers exploited their workers, despite years of negative press coverage. Sometimes companies operating in low cost countries include clauses in their contractual agreements with suppliers stipulating that they must abide by national laws and/or international principles established by the United Nations Guiding Principles on Business and Human Rights (UNGP) and United Nations Global Compact (UNGC) in their operations. This can be a standard clause in all the company's contracts. However, even if the supplier signed the contract, the majority of buyers do not have intentions nor resources to conduct proper due diligence and actually show up at the factory to check that the agreement is fulfilled. Some companies that actually conduct on-site inspections, it might turn out that the supplier has several facilities with different working conditions. Whereas the

\footnotetext{
${ }^{36} \mathrm{https} / / /$ www.ft.com/content/f9d84f0e-e509-11e4-8b61-00144feab7de.

${ }^{37}$ https://www.reuters.com/article/us-bangladesh-budget/bangladesh-budget-offers-minorincentives-for-garment-industry-safety-idUSKBN0EG1N020140605.
} 
visited factory might fulfil the terms of the agreement with regards to working conditions, the supplier could actually fulfill the order from other locations, which do are not within the scope of the agreement. When Nike implemented a code of conduct, it did not create a rigorous process for actually monitoring suppliers' adherence.

In the Arthur Andersen and Volkswagen cases, employees at different levels must have been aware that their respective firms were "bending" the rules for quite some time. The schemes were too complex and involved too many people to place blame on only one person. It was evident that ignoring such transgressions had become part of the company culture. Employees who were aware of the facts were less likely to report them. Arguments that "This has been going on for a long time", "It is not my responsibility", "Everybody else does it the same way" are typical arguments for claiming ignorance. It is also uncomfortable to report on colleagues that they are not behaving in accordance with the law or bending the rules to accommodate this borderline behavior. Arthur Andersen auditors somehow did not catch that Enron inflated its revenues for years and hid debt. After Enron collapsed, Arthur Andersen claimed Enron held back information during audits and it failed due to its business model.

These kinds of rationalizations can be explained by neutralization theory (Sykes \& Matza, 1957). People use one or more sets of argument to neutralize irresponsible behavior. Applying neutralization theory to the VW case would be along these lines:

- Denial of responsibility (It was not my fault; I only did what I was asked to. All our competitors are doing it too.)

- Denial of injury (It was not a big deal; emissions from these cars are very low anyways.)

- Denial of the victim (Every car pollutes; this does not make a difference.)

- Condemnation of the condemners (the managers are to blame; they knew about the defect devices and did not tell us to stop.)

- Appeal to higher loyalties justifies what is objectively irresponsible (if I told anybody about the defect device, I would lose my job. I have three children and cannot afford to be unemployed.) 
In the Rana Plaza case, the tragedy did not challenge the reputation of just a single company, but numerous global companies sourcing from five different factories operating within the complex. Some of the companies involved were large well-known brands such as Benetton, Primark, and C\&A. As noted in the case, Benetton initially denied any sourcing contracts at Rana Plaza. The irony of Benetton is that its core marketing focuses on developing a multicultural and socially conscious brand image. However, other firms such as Mango downplayed their role, noting they just ordered samples without a formal commercial relationship.

\section{Stage 2: React}

After being passive, companies are pushed to become active and respond to the deleterious event or incident. There are different reasons these four cases caught the public's attention, making it necessary for the companies to respond to accusations. Throughout the 1990s, numerous newspapers, magazines, TV programs, and media within Asia were covering the exploitive working conditions at Nike's supplier's factories.

At Arthur Andersen, a massive quarterly loss at Enron and subsequent SEC investigation precipitated a revelation of Enron's fraud, inducing a reaction from Arthur Andersen, their external auditors, who for years certified their books were in order.

In the Volkswagen case, after so many years of the cheating emissions testing, three researchers from UWV presented their surprising diesel emissions research at a conference attended by the head of the California Air Resources Board (CARB), who immediately started an investigation. And in the Rana Plaza case, the collapse of the building and high death toll triggered an international media storm.

It is when the incidents become public that the companies are bounded to react. The cases are all based on issues that have been going on for quite some time internally. If the cases had been resolved then, there would have been no public case to react to. So, there are two types of reaction; internal reactions to avoid public cases and ignorance over time, which finally result in public cases. This is yet another reason for following up possible cases internally, and, most important of all, avoid having unacceptable practices going on in the company. 


\section{Stage 3: Defend}

There are generally two approaches companies use in defense; they either deny there is a problem or defend themselves from accusations, claiming for example that it is not the company's fault or that the company is not responsible.

In the Nike case, the firm strongly denied allegations for years. Later, as more convincing media reports surfaced and an external auditing report pointed to the same, the company was explicitly aware of the workers' exploitation. Nike continued handling the situation as a PR problem but addressed it more directly. In public statements, Nike maintained it was not the company's responsibility to investigate working conditions of its suppliers.

Arthur Andersen denied previous knowledge of Enron's fraudulent practices, claiming that its business model failed and that its executives withheld information from Arthur Andersen's partners. First it denied wrongdoing, noting it was a standard policy to dispose of unnecessary documents. Arthur Andersen would also later deny knowledge of the order from the HQ level to destroy the documentation, spinning it to be the work of a rouge partner.

Whereas Primark in the Rana Plaza case quickly acknowledged they sourced garments from Rana Plaza and pledged to compensate the victims, Benetton completely denied any business relationship hence culpability. Then as Benetton labels and documentation surfaced days later, this turned out that was not the case. They were bounded to react.

When confronted by the EPA and CARB with data showing discrepancies in emissions, VW attributed them to technicalities, indirectly denying there was anything further to investigate. It also issued a limited recall. When the EPA threatened to not allow VW's 2016 diesel cars to be sold on the US market without further clarification, VW was pressed to respond.

\section{Stage 4: Accommodate}

At this stage, firms concede by acknowledging their bad behavior and/or mistakes in order to move on from the scandal. By taking responsibility, expressing regret and concern, and providing a comprehensive list of 
corrective actions, they put themselves in a position to accommodate criticism. This open approach consequently takes away the interest of media. Acknowledgment and regret-even though the company might not fully agree that they did something wrong - is the typical approach. Also, it is a common practice to replace the CEO, whether or not the CEO is directly involved, demonstrating accountability in their leadership.

The culmination of negative press coverage and active human rights groups made the Nike CEO concerned with Nike's reputation and whether these accusations were finally impacting growth. He publicly acknowledged their brand became synonymous with exploitation of labor and embarked on turning around Nike image. They implemented a rigid monitoring system of their suppliers' working conditions with local Nike employees, created a corporate responsibility and compliance division issuing annual reports, engaged their hardest critics, and published their supplier list for transparency.

Two years after the Rana Plaza collapse, Benetton's new CEO stated, "We accept and agree that it's a shared responsibility for those who were there." Immediately after the accident, Benetton donated 500,000 to the largest international NGO, Bangladesh Rural Advancement Committee (BRAC), which collected money for victims. However, donating to a charity avoids the presumption of responsibly and liability. It is different than directly compensating the Rana Plaza victims. After consulting with PwC to establish a reasonable amount, Benetton finally paid $\$ 1.1 \mathrm{~m}$ into The Rana Plaza Trust Fund to compensate the victims and their families. They excused the delay based on how the fund provided no guidance and contributions were voluntary. At this point, Benetton considered the Rana Plaza matter closed on its part. Going forward it would upgrade and consolidate its supply chain as well as collaborate with other brands on safety initiatives.

After the EPA's threat to ban VW diesel cars on the US market, the company admitted to regulators it manipulated emissions tests with defect devices. The CEO denied knowledge, but accepted the responsibility for the irregularities in emissions, formally submitting his resignation. Since VW pleaded guilty to three criminal offenses and paid over $\$ 34.69 \mathrm{~B}$ in fines and settlements. VW and its subsidiaries, Audi and Porsche were also not allowed to sell any new or used diesel cars on the US market for the two years. 
Whereas the Arthur Andersen case ended quite differently. The firm went bankrupt and the accommodation stage was not a relevant option. It lost most of its clients after the indictment. The CEO stated, "The fact is that improper shredding of documents took place on my watch ... it is now in the best interest of the firm for me to step down from the CEO position." Arthur Andersen was found guilty, but continuously defended it did nothing wrong. Years later, Arthur Andersen was exonerated in a unanimous verdict by the highest court in the United States, the Supreme Court. The judges called the case by the government prosecutors, "weird". The jury was never instructed to find a link between the document destruction and any official investigation in which the documents were requested. However, it would later come to light that Arthur Andersen was the external auditor in a number of scandals involving fraudulent accounting, such as WorldCom, Waste Management, and Sunbeam Products. As a result, its collapse led to systematic change in the auditing industry. Auditors would be more willing to stand up to clients, comprehensive legislations (Sarbanes-Oxley Act) were enacted, and regulatory agencies created, and it actually made the industry more profitable, generated a lot more demand for accountants and lawyers.

In general, the first move when such deleterious incidents are uncovered is to go through the company processes to find out how this could have happened. The next step is to repair the system. When the company has reached a level where they perceive themselves as in control and having a complete overview of their responsibilities, they can either finish there or move to the next step-proactive.

\section{Stage 5: Proactive}

Tragedies and crisis are inflection points, which create opportunities as the common saying goes, "Never waste a good crisis". That is what Nike did. The company was one of the first, if not the first, company to be open about all their suppliers and transparently published them. Anyone can now consult Nike's websites and see where the products are produced. That can be categorized as advanced Accommodation. Nike also moved to the next stage with regards to products. It has promoted 
environmental issues through its product design. Today 75 percent of all Nike products contain some recycled material, and in the industry, no one uses more recycled polyester (Nike News, 2018). Nike also has a reuse-a-shoe program where shoes (including athletic shoes from other manufacturers) at the end of their life can be dropped off at a participating Nike retail store. The shoes then become part of a recycling process and are designed to accommodate for this circularity process. Nike's circular principles will be further addressed in the next chapter on circular economy.

Nike has also made controversial decisions to support social issues, when for example it signed Colin Kaepernick, a civil rights activist and former American football quarterback, who kneeled during the US national anthem to protest police brutality and racial inequality. It was a choice between David (Kaepernick) and Goliath (NFL) for Nike. After he played out his contract, not a single NFL team would sign him on as a player. Instead, Nike ran the campaign "Believe in something. Even if it means sacrificing everything. Just do it." It was good for business, increasing Nike's value by $\$ 6 \mathrm{~b}$. Although very risky, its success even led to accusations of commercializing social justice, the direct opposite of its image in the 1990s. It was not only social issues that became part of Nike's strategy. In 2019, Nike launched its “Move to Zero" strategy, fighting environmental and climate change.

Brands that outsourced from Rana Plaza complex, engaged in several initiatives to improve the situation, both through industry networking and more global initiatives in cooperation with governments and NGOs. Supply chain labor standards initiatives like the Ethical Trading Initiative (ETI) received increased attention, and issues like maximum working hours, minimum pay, employees' freedom of association, investigating of previous poor conditions, and so on were followed up. Country level multi-stakeholder initiatives, initiatives that include the workers into the process, workers helpline for reporting and assistance, robust monitoring, increased transparency, capacity building, brand buyer accountability and better sourcing and purchasing practices, aligning targets and incentives are examples of initiative resulting from the Rana Plaza collapse. These initiatives were not only associated with factories in the Rana Plaza area, but in the sweatshop in industry in general (see Chap. 4 on 
regulations associated with Human Rights and Corporations). Global brands and NGOs have also become more conscious and active in conducting building safety inspections in their audits, something they didn't consider doing before the tragedy. In Bangladesh, many firms joined the ACCORD initiative and have pulled out orders from garment factories from which operations are housing in unsafe buildings.

VW also moved into the proactive stage. It announced it would stop manufacturing gas and diesel engines by 2026 and focus on electric cars. $\mathrm{VW}$ is in the process of transforming itself to be a pioneer in sustainable mobility with the goal of becoming carbon neutral by 2050 .

Evident from the tragedies and scandals presented in the cases above, unsustainable development can have major negative repercussions for companies. The immediate interventions of companies from a sustainability standpoint are therefore, not surprisingly, to reduce contagion and mitigate further risks for such incidents.

\subsection{Business Models for Sustainability}

The risk of negative effect of behaving irresponsible and the opportunity for better business when behaving responsible and sustainable have made companies to take a proactive approach to sustainability. Integrating sustainability into the company's identity is becoming increasingly common.

Companies do not have to go through the Five Stages of the model to respond to scandals and tragedies. Rather, by not ignoring potential challenges and opportunities, companies are maybe already at the "Accommodate" stage, having implemented at sustainability program that identified what to do. Changing the company's name and vision is also part of the accommodation process and can also be part of advancing to the proactive stage. Today, about 12 percent of companies in the S\&P 500 list address the triple bottom line in their strategy documents, "caring for the people" and "safeguarding the planet" appeared respectively in 34 and almost 15 percent of the companies (Baral \& Pokharel, 2017)

In Chap. 7 Strategy to approach sustainability in companies, the necessity of anchoring the work on sustainability in top management is put 
forward. New more sustainable visions and missions are crucial, and examples of how this is applied in companies are provided.

Today, most large companies are in stage four, improving social and environmental performance through reducing negative impact. In order to attain a sustainable future, companies have to move to stage fiveactive. The real opportunities in a sustainability setting are the business opportunities.

A business model is about Creating, Delivering, and Capturing Value (Kapland, 2012). To pursue a sustainable future, new and more sustainable elements must be included in the model — and the final product will be different and more sustainable. The three elements of the business model have to be extended to include social and environmental issues.

If the cost of gasoline reflected its external environmental and social cost, the price per liter would be multiplied, and the variables in the business model will have to include that. The company still has to create, deliver, and capture value-only that the outcome of the model, the product, and the value are changed. The companies which are succeeding in this process are the ones which manage to redesign the product to be more sustainable — and still preferred by consumers. Limiting production can contribute to increased profit and thus reducing the use of resource. Collaboration between different disciplines such as ecology, psychology, and sociology is necessary to change production and consumption and ensure the negative impact of products is minimized — and the SDGs are great tools to evaluate the impact.

During the COVID-19 pandemic, many companies had to change their business models. Companies with a business model delivering an Active holiday experience in Africa, had to change to providing an Active holiday experience in Norway, since people in Norway were not allowed to leave the country. But it is not only pandemics that have the capacity to change business models, it is also the introduction of taxes reflecting the product's external costs that lead to changes in business models. With an increase in fuel prices, long distance travelling has become more expensive and less people can afford too far. Then too it can be an alternative and good business model to focus on local holiday experiences. Some companies are agile and manage this shift in a business model well, whereas other companies do not cope well with new situations and fail to 
change their business models. To be prepared for environmental and social challenges, the business model of a company has to move to the "Proactive" phase.

New companies today often emerge directly from the "Proactive" stage of the model. Some examples of new companies' business models that have a purpose, which contributes to sustainable development, include Airbnb and TooGoodToGo. Airbnb facilitates sharing housing. TooGoodToGo sells left over food with the purpose of "Save the Food help the Planet".

A system change to a circular economy is a promising business model and a good example of the proactive stage of doing business. This will be the focus in the next chapter.

In the midst of chaos, there is also opportunity.

\section{References}

Baral, N., \& Pokharel, M. P. (2017). How sustainability is reflected in the S\&P 500 companies' strategic documents. Organization \& Environment, 30(2), 122-141. https://doi.org/10.1177/1086026616645381. https://login. ezproxy.library.bi.no/login?qurl=https://search.ebscohost.com/login.aspx?dir ect $=$ true $\& \mathrm{db}=\mathrm{bth} \& A \mathrm{~N}=123161373 \&$ site $=$ ehost-live \&scope $=$ site

Bhattacharya, C. B., Sen, S., \& Korschun, D. (2008). Using corporate social responsibility to win the war for talent. MIT Sloan Management Review, $49(2), 37$.

Brand Finance. (2015, September 25). VW risks its $\$ 31$ billion brand and Germany's national reputation. https://brandfinance.com/press-releases/ vw-risks-its-31-billion-brand-and-germanys-national-reputation

DiMaggio, P. J., \& Powell, W. W. (1983). The iron cage revisited: Institutional isomorphism and collective rationality in organizational fields. American Sociological Review, 48, 147-160.

Ditlev-Simonsen, C. D. (2010). From corporate social responsibility awareness to action? Social Responsibility Journal, 6(3), 452-468. https://doi. org/10.1108/17471111011064807 
Ditlev-Simonsen, C. D. (2014). Are non-financial (CSR) reports trustworthy? A study of the extent to which non-financial reports reflect the media' perception of the company's behaviour. Issues in Social and Environmental Accounting, 8(2), 116-133. https://doi.org/10.22164/isea.v8i2.85

Ditlev-Simonsen, C. D., \& Midttun, A. (2011). What motivates managers to pursue corporate responsibility? A survey among key stakeholders. Corporate Social Responsibility and Environmental Management, 18(1), 25-38.

Fombrun, C. J. (2005). Building corporate reputation through CSR initiatives: Evolving standards. Corporate Reputation Review, 8(1), 7.

Freeman, R. E. (1984). Strategic management: A stakeholder approach. Pitman. Friedman, M. (1970). A Friedman doctrine-The social responsibility of business is to increase its profits. The New York Times. https://www.nytimes. com/1970/09/13/archives/a-friedman-doctrine-the-social-responsibility-ofbusiness-is-to.html

Hoffmann, A. J. (2018). The next phase of business sustainability. Stanford Social Innovation Review, 16(2), 34-39. https://ssir.org/articles/entry/the_ next_phase_of_business_sustainability

Hursthouse, R. (1999). On virtue ethics. Oxford University Press.

Jensen, M. (2001). Value maximisation, stakeholder theory, and the corporate objective function. European Financial Management: The Journal of the European Financial Management Association, 7(3), 297-317. https://doi. org/10.1111/1468-036x.00158

Juetten, M. (2014). Pay attention to innovation and intangibles-They're more than $80 \%$ Of your business' value. Forbes. https://www.forbes.com/sites/ maryjuetten/2014/10/02/pay-attention-to-innovation-and-intangiblesmore-than-80-of-your-business-value/?sh=12c143b11a67

Kanter, R. M. (1999). From spare change to real change. The social sector as beta site for business innovation. Harvard Business Review, 77(3), 122-210.

Kapland, S. (2012). The business model innovation factory: How to stay relevant when the world is changing. In Business models 101: Creating delivering, and capturing value. Wiley. https://doi.org/10.1002/9781119205234

Nike News. (2018, May 15). Nike's latest sustainable innovations and environmental impact. https://news.nike.com/news/sustainable-innovation-airbag-manufacture

Porter, M. E. (1998). Clusters and the new economics of competition. Harvard Business Review, 76(6), 77-90.

Sustainable Brands. (2019, July 3). Measuring and managing brand reputation: How CSR and other factors influence reputational value [Video]. YouTube. https://www.youtube.com/watch?v=JKzZlyJD1Z0 
Sykes, G., \& Matza, D. (1957). Techniques of neutralization: A theory of delinquency. American Sociological Review, 22(6), 664-670. https://doi. org/10.2307/2089195

Williamson, O. E. (1964). The economics of discretionary behavior: Managerial objectives in a theory of the firm. Prentice Hall.

Wilson, I. H. (1975). What one company is doing about today's demands on business. In G. A. Steiner (Ed.), Changing business-society interrelationship. Graduate School of Management, UCLA.

World Commission on Environment and Development. (1987). Our common future. https://sustainabledevelopment.un.org/content/documents/5987ourcommon-future.pdf

Zadek, S. (2004, December). The path to corporate responsibility. Harvard Business Review. https://hbr.org/2004/12/the-path-to-corporate-responsibility

Open Access This chapter is licensed under the terms of the Creative Commons Attribution 4.0 International License (http://creativecommons.org/licenses/ by/4.0/), which permits use, sharing, adaptation, distribution and reproduction in any medium or format, as long as you give appropriate credit to the original author(s) and the source, provide a link to the Creative Commons licence and indicate if changes were made.

The images or other third party material in this chapter are included in the chapter's Creative Commons licence, unless indicated otherwise in a credit line to the material. If material is not included in the chapter's Creative Commons licence and your intended use is not permitted by statutory regulation or exceeds the permitted use, you will need to obtain permission directly from the copyright holder.

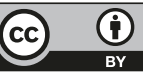

